\title{
臨床教育と連続性のあるシミュレーション教育の重要性 一成人教育原理の重要性一
}

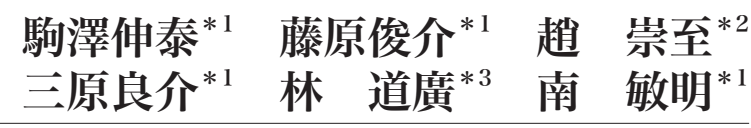

[要旨] シミュレーション教育の質の維持には, (1)常にコース内容のフィードバックを行い質の改 善を行う, (2)学習目標の明確化, (3)インストラクターの指導技術の研鑽が重要である. さらに, シ ミュレーション教育を臨床医学へのテクニカル・ノンテクニカルスキル向上へ応用するには, その 伝導者であるインストラクターによる意識付けが必須である. 米国心臓協会の主催する救命処置の インストラクターへの必須条件として, コアインストラクターコース受講がある. これはコーチン グ等の成人教育原理を重視しており, 臨床教育においても十分活用できるため, 本稿ではインスト ラクターに求められる20の能力について紹介する. シミュレーション教育を臨床研修に応用し連 結するためには指導能力の研鑽は重要と考えられる. キーワード : シミュレーション教育, 臨床研修, 成人教育原理

\section{はじめに}

現在，医学教育のさまざまな側面でシミュレーシ ヨン教育が開発されているが，インストラクターの 能力により学習目標や効果が不明瞭になることもあ る.さらに, 高度なテクニカルスキルの取得を重視 するあまり，ノンテクニカルスキルの習得が必然的 におろそかになることも危惧される ${ }^{1)}$.

シミュレーション教育の質の維持には，(1)常にコ 一ス内容の自己および受講生からの評価を受け改善 していくこと, (2)学習目標の明確化, (3)インストラ クターのインストラクションテクニックが重要であ る(図1)。(1)および(2)は, 各種世話人会等の母体組 織によるクオリティコントロールが重要であるが,

${ }^{* 1}$ 大阪医科大学麻酔科学教室

*2 松下記念病院麻酔科

*3 大阪医科大学消化器外科学教室
(3)は個人の努力が必須である.

本稿では，米国心臓協会 (American Heart Association, 以下 AHA)が心肺蘇生のインストラクター 養成にあたり提唱している 20 の能力について概説 する ${ }^{2,3)}$.

\section{I 成人教育原理と AHA インストラクターに 求められる20の能力}

AHAの主催する一次救命処置, 二次救命処置の インストラクターコース受講の必須条件としてコア インストラクターコースの受講がある。これはコー チング等の成人教育原理を重視しており, 臨床教育 においても十分活用できる内容である。AHAの成 人教育原理は徒弟制といった封建的な䨌囲気がいま 


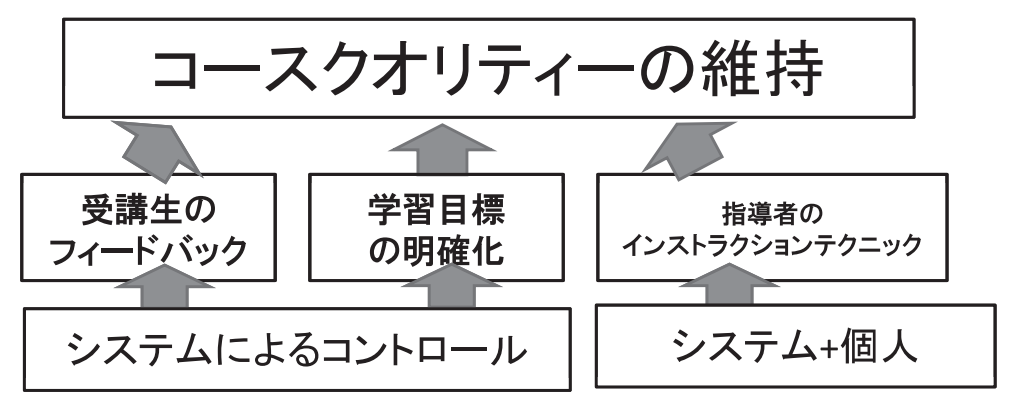

図1 シミュレーション講習会の質の維持に必要な項目

だ残存する本邦の医療技能指導とは異なる面が多 い. 成人教育原理は, 自発的な学習意欲の活性化と 行動変容を起こすことを目的としている ${ }^{4)}$. 以下に AHAのインストラクターに求められる 20 の目標に ついて, (1)プロフェッショナルとしての基礎，(2)計 画と準備，(3)管理，(4)指導方法，(5)評価について， 記載する(表 1)。

(1)プロフェッショナルとしての基礎

指導のプロフェッショナルとしての基礎として倫 理や法律を守ることやプロフェッショナルとしての 信頼性を確立するために，その分野の知識やスキル を改善していくことは当然であると考えられる. AHA はさらにインストラクターに対し, 効果的に コミュニケーションを図ることを提唱している。特 に言葉だけでなく態度, 服装, 体の向き, 机の配置 などの非言語的なコミュニケーションを重視してい る。インストラクターと受講生の良好なコミュニケ ーション確立が第一であり, 受講生の性格や文化的 背景も配慮するように示唆している。実際, 市販さ れているコアインストラクターコースのテキストに は人種別の性質が記載されている ${ }^{3)}$.

(2)計画と準備

AHA は講習会に向けた指導の事前準備を特に強 調している。コアインストラクターコースのテキス トには事前何週，何日前までに何を行うべきか，な ぞも具体的に記載されている.さらにコースの教材 やマネキン等の物品準備に関しても，コースが始ま つた後のトラブルシューティングは時間や受講生信
頼度の大きな低下につながるため事前の確認が重要 である。

(3)管理

ここでいう管理というのは，(2)の計画と準備と同 じく受講生がコースを受けやすい環境を管理するこ とである。すなわち，学習や実技に集中しやすいよ うなスペース, 椅子と机の配置, メディア機器の適 切使用や音量の調整等隅々までの配慮が必要とな る.

(4)指導の方法

この8つの項目はインストラクターとしての能力 の根幹的なものであるが，これらの目的を達成する ためにも (1)〜3)の環境調整が前提になる。これらの 8つの項目のうち，まず注目すべきは，「受講者の 動機付けと参加意欲促進」である。受講生がコース 受講時を通して参加意欲を失わないように，プレゼ ンテーションだけでなく，進行役としてのファシリ テーションスキルが求められる。例えば，意欲の少 ない受講生には, 自己の経験についての質問を行い, 彼らの回答からコース受講の意義を気づかせること もスキルの一つといえる。長時間のコースでも，イ ンストラクターは質問と傾聴を行い受講生の良きフ アシリテーターとなり，明確な目標を提示し続ける ことが重要である。

次に重要なことはAHAがインストラクターに 「知識とスキルの保持，実践力への転用の促進」を 明確に提示していることであろう。これは，臨床と いう実践の現場に生かすことができて初めてシミュ 
表 1 AHA コアインストラクターコーステキストにあ るインストラクターに求められる20の目標

プロフェッショナルとしての基礎

1 効果的にコミュニケーションする

2 専門的知識とスキルを更新し改善する

3 倫理・法律上の基準を遵守する

4 プロフェッショナルとしての信頼性を確立する

5 文化的背景に配慮を示す

計画と準備

6 指導の方法と教材について計画する

7 指導の事前準備をする

管理

8 学習と実技を促進する環境を管理する

9 適切なテクノロジーを用いた指導手順を管理する

指導の方法と方略

10 受講者の動機付けと参加意欲を促進し維持する

11 効果的なプレゼンテーションスキルを示す

12 効果的なファシリテーションスキルを示す

13 メディアとテクノロジー

14 質問と傾聴

15 明確化とフィードバックを行う

16 知識とスキルの保持を促進する

17 知識とスキルの実践力への転用を促進する

評価

18 学習と実技を評価する

19 指導の効果を評価する

20 補習を行う

レーション教育は意義があるということを明言して いるといえる。インストラクターはこのことを忘れ ず，常に臨床への還元を考慮してシミュレーション 教育に臨むべきである ${ }^{5) ~ 7) . ~}$

(5)評価

シミュレーション講習会が有効であったかどう か, 受講生がテクニカルスキルおよびノンテクニカ ルスキルを身に付けているか評価を行うことはコー ス受講の意義を確認する目的からも必須である. 実 際, AHA は一次救命処置コースでも二次救命処置 コースでも実技および筆記試験を行っており，その 合格をコース終了の必須条件としている。さらに特 筆すべきは補習という概念である，英語の原文では
Remediation とあるがこれは修正，矯正という意味 である. 合格, 不合格という意味ではなく, 学習しき れなかった側面を補うという意味と考えられる ${ }^{8), 9}$.

\section{II シミュレーション教育の臨床応用}

講義を中心とした知識の蓄積と応用というこれま での医学教育法では, 高度複雑化した現代医療の教 育には不十分な可能性がある。特に麻酔や救急など のクリティカルケアの分野では, 急変時の状況は多 様となる ${ }^{10)}$. 知識のみや技術のみ単独の習得では対 応が難しく, 実際の複雑な臨床状況に即した総合的 な対応が必要である。卒前，卒後を問わずシミュレ ーション教育が急速に普及している。シミュレータ 一は臨床上では評価できない事象の検証ができるだ けでなく ${ }^{11)}$ 12), 教育に活用することができる.シミ ユレーション教育は，患者を危険にさらすことなく 繰り返し訓練でき, 発生頻度は低いが生命危機に陥 りうる事態に対する対処を学ぶことができる ${ }^{13)}$. シ ミュレーション教育は, さまざまな医学の分野で有 効な学習方法として発展し, スキルの取得だけでな く, 医療安全への貢献も期待される.

このようにシミュレーション教育に期待される役 割は大きく, 臨床医学へのテクニカル・ノンテクニ カルスキル向上へ応用するには，その伝導者である インストラクターの指導能力が必須である。本稿で 紹介した AHAのインストラクターに求められる 20 の能力は臨床教育を行う上でも重要と考えられ, 臨 床指導医がシミュレーション教育を行う際に共通の 指標とできると考えられる。 さらにシミュレーショ ン教育の指導を行うことにより，良き臨床指導医と しての能力を涵養できる可能性もある.

臨床上の問題点からシミュレーション教育が生ま れ, シミュレーション教育は臨床教育に還元するこ とが大切である (図 2)。この臨床応用には成人教育 原理が大切と考えられる。 
臨床応用

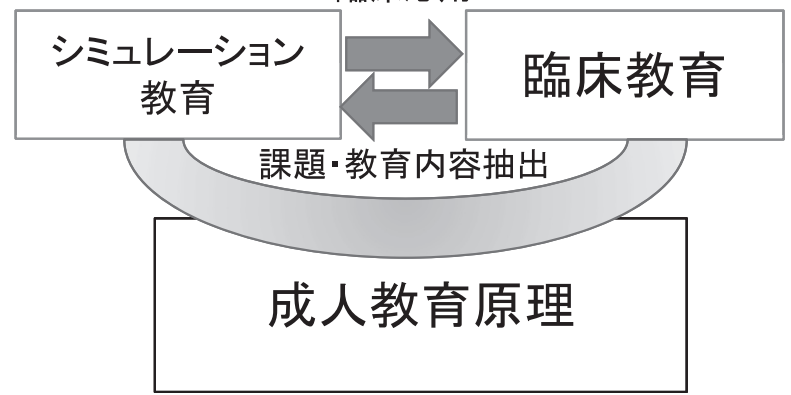

図2 成人教育原理がつなぐシミュレーション教育と 臨床研修

\section{結＼cjkstart語}

米国心臓協会のインストラクターに求められる 20 の能力について紹介した。シミュレーション教 育を臨床に連結し応用するためには指導能力の研鑽 は重要である。

\section{参考文献}

1）駒澤伸泰, 藤原俊介, 南敏明：麻醉・救急領域におけ る医療安全向上のためのシミュレーション教育の意義 と課題. 日臨麻会誌 $34: 214-221,2014$

2) Bhanji F, Mancini ME, Sinz E, et al. : Part $16:$ education, implementation, and teams : 2010 American Heart Association Guidelines for Cardiopulmonary Resuscitation and Emergency Cardiovascular Care. Circulation 122 (Suppl 3) : S920-S933, 2010

3) American Heart Association : AHA コアインストラク ターコースパッケージ。 シナジー, 東京, 2008

4) Shah A, Carter T, Kuwani T, et al. : Simulation to develop tomorrow's medical registrar. Clin Teach 10 : $42-46,2013$
5) Komasawa N, Fujiwara S, Atagi K, et al. : Effects of a simulation-based sedation training course on non-anesthesiologists' attitudes toward sedation and analgesia. J Anesth $28: 785-789,2014$

6) Lynch B, Einspruch EL, Nichol G, et al. : Effectiveness of a 30-min CPR self-instruction program for lay responders : a controlled randomized study. Resuscitation $67: 31-43,2005$

7) Einspruch EL, Lynch B, Aufderheide TP, et al. : Retention of CPR skills learned in a traditional AHA Heartsaver course versus 30 -min video self-training : a controlled randomized study. Resuscitation $74: 476^{-}$ 486, 2007

8) Komasawa N, Sanuki T, Fujiwara S, et al. : Significance of debriefing methods in simulation-based sedation training courses for medical safety improvement in Japan. Springerplus $3: 637,2014$

9）羽場政法, 駒澤伸泰, 藤原俊介ほか：安全な鎮静・鎮 痛法の講習会の改良に向けて一プレテスト・ポストテ ストによる習熟度評価の導入一。 日臨麻会誌 $34 ： 583-$ 587, 2014

10) Sandahl C, Gustafsson H, Wallin CJ, et al. : Simulation team training for improved teamwork in an intensive care unit. Int J Health Care Qual Assur $26: 174-188$, 2013

11) Komasawa N, Ueki R, Yamamoto N, et al. : Comparison of air- $Q^{\circledast}$ and Soft Seal ${ }^{\circledast}$ laryngeal mask for airway management by novice doctors during infant chest compression : a manikin study. Resuscitation $83: 365^{-}$ 368, 2012

12) Komasawa N, Ueki R, Yamamoto N, et al. : Comparison of Pentax-AWS Airwayscope, Airtraq and Miller laryngoscope for tracheal intubation by novice doctors during infant cardiopulmonary resuscitation simulation : a randomized crossover trial. J Anesth $27: 778^{-}$ 780, 2013

13) Fanning RM, Gaba DM : The role of debriefing in simulation-based learning. Simul Healthc $2: 115-125,2007$ 


\title{
Simulation Education Should Be Tightly Linked with Clinical Training
}

\author{
Nobuyasu KOMASAWA*1, Shunsuke FUJIWARA ${ }^{* 1}$, Takashi CHO ${ }^{* 2}$, \\ Ryosuke MIHARA*1, Michihiro HAYASHI ${ }^{* 3}$, Toshiaki MINAMI*1 \\ ${ }^{* 1}$ Department of Anesthesiology, Osaka Medical College \\ ${ }^{* 2}$ Department of Anesthesiology, Matsushita Memorial Hospital \\ ${ }^{* 3}$ Department of General Surgery, Osaka Medical College
}

Although various simulation training courses exist, some are vague in their objectives and effects. Some courses place excessive focus on acquiring technical skills, and underestimate the importance of non-technical aspects. In order to maximize the effect of simulation training courses, simulation education should be tightly linked with clinical training. Here, we introduce 20 points of instruction based on the American Heart Association's adult education principle, which can be applied to both simulation training and clinical education.

Key Words : Simulation training, Clinical training, Adult education principle

The Journal of Japan Society for Clinical Anesthesia Vol.36 No.5, 2016 